\title{
Histone deacetylase inhibition in the treatment of acute myeloid leukemia: the effects of valproic acid on leukemic cells, and the clinical and experimental evidence for combining valproic acid with other antileukemic agents
}

\author{
Hanne Fredly ${ }^{1 *}$, Bjørn Tore Gjertsen ${ }^{1,2}$ and Øystein Bruserud ${ }^{1,2}$
}

\begin{abstract}
Several new therapeutic strategies are now considered for acute myeloid leukemia (AML) patients unfit for intensive chemotherapy, including modulation of protein lysine acetylation through inhibition of histone deacetylases (HDACs). These enzymes alter the acetylation of several proteins, including histones and transcription factors, as well as several other proteins directly involved in the regulation of cell proliferation, differentiation and apoptosis. Valproic acid (VPA) is a HDAC inhibitor that has been investigated in several clinical AML studies, usually in combination with all-trans retinoic acid (ATRA) for treatment of patients unfit for intensive chemotherapy, for example older patients, and many of these patients have relapsed or primary resistant leukemia. The toxicity of VPA in these patients is low and complete hematological remission lasting for several months has been reported for a few patients ( $<5 \%$ of included patients), but increased peripheral blood platelet counts are seen for 30 to $40 \%$ of patients and may last for up to 1 to 2 years. We review the biological effects of VPA on human AML cells, the results from clinical studies of VPA in the treatment of AML and the evidence for combining VPA with new targeted therapy. However, it should be emphasized that VPA has not been investigated in randomized clinical studies. Despite this lack of randomized studies, we conclude that disease-stabilizing treatment including VPA should be considered especially in unfit patients, because the possibility of improving normal blood values has been documented in several studies and the risk of clinically relevant toxicity is minimal.
\end{abstract}

Keywords: Acute myeloid leukemia, Older patients, Disease stabilization, Valproic acid

\section{Introduction}

Acute myeloid leukemia (AML) is caused by clonal expansion of myeloblasts that have lost the normal regulation of differentiation and proliferation; this causes bone marrow accumulation of the leukemic cells, and thereby general bone marrow failure, and eventually leukemization and organ infiltration [1]. The median age at the time of diagnosis is 65 to 70 years. Although the prognosis of AML has improved during the last decade, this is mainly true for younger adults who can receive the most intensive

\footnotetext{
*Correspondence: hanne.fredly@med.uib.no

'Section for Hematology, Institute of Medicine, University of Bergen, N-5021, Bergen, Norway

Full list of author information is available at the end of the article
}

treatment, including stem cell transplantation, whereas the overall survival (OS) for older AML patients remains poor [2].

The conventional intensive chemotherapy for AML usually has a treatment-related mortality of approximately $5 \%$ [3]. The early mortality for patients receiving allogeneic stem cell transplantation is approximately 20 to $25 \%$, even for patients without severe comorbidity [4]. Thus, a large group of patients will be unfit for the most intensive therapeutic strategies due to age $[5,6]$, severe non-hematological diseases, reflected in their comorbidity score [7], or poor performance status $[6,8]$. Another group of older patients should not receive intensive chemotherapy with the intention of remission induction because they have high-risk 
disease and remission is unlikely $[6,7,9]$. In these patients, less intensive treatment based on histone deacetylase (HDAC) inhibition may be an alternative, either alone or in combination with other low-toxic strategies [10].

\section{Valproic acid (VPA) in combination with all-trans retinoic acid (ATRA) \\ Biological and clinical effects of VPA}

Valproic acid (VPA) is a short-chain fatty acid that is an established antiepileptic agent, with proven activity also in bipolar disorder, migraine and neuropathic pain [11]. It is generally well tolerated, but use of VPA in early pregnancy is associated with an increased risk of congenital malformations, including spina bifida in 1 to $2 \%$ of cases, and the malformations seem to be related to the drug's anti-tumor properties [12].

VPA functions as a powerful HDAC inhibitor [13]. Acetylation is one of the main histone modifications leading to the opening of chromatin and promoting gene transcription, whereas histone deacetylation promotes chromatin condensation and represses gene transcription [14]. HDACs are overexpressed in malignant tissue, including leukemic blasts [15]. HDAC inhibitors may therefore result in re-expression of silenced tumor suppressor genes in cancer cells, and potentially lead to cellular differentiation and apoptosis [14].

VPA has a wide range of effects on AML cells and the results from previous studies are summarized in Table 1 [16-38]. These observations clearly demonstrate that VPA can induce differentiation, and has antiproliferative and proapoptotic effects in AML cells. However, patients are most likely heterogeneous with regard to both susceptibility to VPA and molecular mechanisms mediating the antileukemic effects. Direct effects on the leukemic cells seem most important, but indirect effects mediated through increased antileukemic immune reactivity may also contribute. Few studies have explored VPA as monotherapy in AML $[39,40]$ and only low response rates have been seen ( 3 to $5 \%$ ).

Biological and clinical effects of ATRA combined with VPA In 1981, all-trans retinoid acid (ATRA) was proven to differentiate human acute promyelocytic leukemia (APL) cells in vitro [41], and ATRA has now changed APL from a highly fatal to a highly curable disease [42-44]. In APL, the absence of ATRA leads to HDAC activities, inducing chromatin condensation and transcriptional repression [45]. Pharmacological levels of ATRA then induce a conformational change in the promyelocytic leukemia (PML)/retinoic acid receptor $\alpha(\mathrm{RAR} \alpha)$ fusion oncoprotein, thereby allowing the release of HDAC complexes and recruitment of transcriptional co-activators with growth suppression and differentiation induction [46].
Several clinical studies have investigated the combination of ATRA and VPA in non-APL variants of AML. This combination has antileukemic activity in experimental in vitro studies [46] and is usually well tolerated by patients. The results of these clinical studies are summarized in Table 2 [19,39,40,47-51]. Based on these results, the following conclusions can be made: 1) the combination of VPA and ATRA has clinically relevant antileukemic activity; 2) the combination is well tolerated, and the most common side effects are dose-dependent and reversible fatigue, and gastrointestinal toxicity; 3) the antileukemic activity can be seen at serum levels below the generally accepted therapeutic levels used for antiepileptic treatment; 4) the treatment is also safe for older patients and can be combined with low-toxicity chemotherapy; 5) a clinical effect is only observed for a minority of patients, and in several studies this is only observed in 20 to $40 \%$ of the included patients; and 6) the most common effect on peripheral blood cells is increased platelet counts, whereas complete hematological remission is very uncommon.

ATRA therapy has dramatically improved the prognosis of APL [42] and has also been used in the treatment of non-APL AML [39,40,48,51]. ATRA toxicity, as reported during treatment of APL, includes the ATRA or APL differentiation syndrome [55]. This syndrome has an incidence of 2 to $27 \%$ and a mortality rate of 2 to $15 \%$ [55,56]. Other frequent side effects include dryness of mucosa, headache, and increased transaminases and triglycerides [55]. Serious side effects of ATRA $45 \mathrm{mg} / \mathrm{m}^{2} / \mathrm{d}$ are very uncommon when VPA plus ATRA are used in the treatment of non-APL AML (Table 2) [47].

\section{VPA in combination with demethylating agents The clinical experience of demethylating agents as monotherapy in human acute myeloid leukemia (AML)}

The nucleoside analogues decitabine and 5-azacitidine (5-AZA) are the two demethylating agents most extensively studied. Decitabine inhibits DNA methyltransferase (DNA MTase) and causes DNA hypomethylation. It has shown convincing activity in myelodysplastic syndrome (MDS) in a large, phase III European trial, including 233 patients aged 60 years or older [57]; $13 \%$ of patients receiving decitabine achieved complete remission (CR) and 6\% achieved partial remission (PR), compared with none in the best supportive care group. In AML, a phase II multicentre study, including 55 patients older than 60 years, $25 \%$ of patients achieved CR and $29 \%$ of patients had stable disease [58].

5-AZA is a ribose structure, which needs to be metabolized by ribonucleotide reductase to be incorporated into DNA; it cannot be combined with hydroxyurea due to pharmacodynamic interactions [59]. 5-AZA has been approved for the treatment of MDS and has demonstrated increased survival, compared to conventional treatment in a randomized phase III study, including 358 patients [60]. 
Table 1 Functional or molecular targeting effects of valproic acid (VPA) on acute myeloid leukemia (AML) cells Intracellular signaling and trafficking

Expression of the CXCR-4 receptor is decreased in CD34- AML cells, whereas increased expression is observed in CD34+ leukemic cells [25]. In vivo treatment with VPA in combination with ATRA alters the phosphorylation status and the phosphoresponsiveness of several intracellular signaling pathways, but the effects differ between patients [35]. VPA increases p21 but downregulates c-Myc expression at a transcriptional level [18]. Modulation of CBP activity and interaction with PML nuclear bodies may contribute to the effects of VPA [38]. The nucleolar morphology and function is altered [36]. VPA also alters the overall expression pattern of the various HDACs [16].

\section{AML cell proliferation, differentiation and apoptosis}

VPA has an antiproliferative effect that is dose-dependent. The effects differ between patients and at lower concentrations even enhancement of proliferation is seen for a subset of patients [37]. VPA reprograms the differentiation program in AML cells, especially in cells with a myelomonocytic phenotype [19]. Animal studies of APL suggest that terminal granulocytic differentiation can also be seen [30]. Differentiation is especially seen in $\mathrm{t}(8 ; 21)$ AML cells [31].

\section{Effects on leukemic stem cells}

In animal models of APL, VPA causes rapid disease regression in induction of granulocytic differentiation, but discontinuation is associated with immediate disease relapse, suggesting that leukemia-initiating cell activity is not affected by VPA [30]. Studies in human cells also suggest that VPA spare or increase immature AML cells during in vitro culture [17]. Direct associations between epigenetic modifications and reprogramming of normal as well as cancer stem cells are now emerging for other malignancies [33].

\section{Effects on $t(8 ; 21)$ AML}

In contrast to other AML subsets, VPA inhibits not only the mature AML cells but also the immature progenitors in AML1/ETO [17]. The drug targets the AML1/ETO-HDAC complex, and thereby alters gene expression and induces differentiation [31]. VPA has specific effects in this AML subset. The drug induces differentiation followed by apoptosis and accompanied by increased expression of repressed AML1 target genes [31].

\section{Effects on antileukemic immune reactivity}

In combination with 5-AZA, VPA causes induction of specific T cell responses against cancer-associated antigens [24]. The drug also increases the susceptibility to NK cell-mediated lysis through upregulation of NK cell ligands on the leukemic cells [32,34]; the NK cells then target leukemic stem cells [29]. This effect is also seen for ATRA [34]. AML cells are also sensitized to TRAIL/Apo2L-induced apoptosis by VPA [27]. Spontaneous in vitro apoptosis is associated with immunogenic apoptosis with HSP release and calreticulin exposure; VPA does not interfere with this expression during stress-induced apoptosis [20].

\section{Chemosensitivity and chemoresistance}

A recent experimental study suggested that VPA induces a broad chemoresistance phenotype in AML cells [26]. However, clinical data does not support this observation since VPA can be combined with cytarabine, hydroxyurea and 6-mercaptopurin in the treatment of AML patients [22,23]. One marker of sensitivity may be UTX (KDM6A), which has a functional relationship between protein acetylation and lysine-specific methylation [21]. Resistance programs have also been identified that compensate for the HDAC inhibitor-induced global hyperacetylation, and these programs include MAPKAPK2, HSP90AA1, HSP90AB1 and ACTB [21]. One study also suggested serum HSP90 as a possible marker of sensitivity to VPA [22]. Cellular high expression of FOSB may be another sensitivity marker [28].

5-AZA, 5-azacytidine; AML, acute myeloid leukemia; APL, acute promyelocytic leukemia; ATRA, all-trans retinoic acid; CXCR-4, C-X-C chemokine receptor type 4; FOSB, FBJ murine osteosarcoma viral oncogene homolog B; HDAC, histone deacetylase; HSP, heat shock protein; HSP90, heat shock protein 90; HSP90AA1, heat shock protein $90 \mathrm{kDa}$ alpha (cytosolic), class A member 1; HSP90AB1, heat shock protein $90 \mathrm{kDa}$ alpha (cytosolic), class B member 1; MAPKAPK2, mitogen-activated protein kinase-activated protein kinase 2; NK, natural killer; PML, promyelocytic leukemia; UTX, ubiquitously transcribed tetratricopeptide repeat, X chromosome; VPA, valproic acid.

The median OS was 24.5 versus 15 months, and after 2 years $50.8 \%$ of patients in the treatment group were alive versus $26.2 \%$ in the conventional treatment group. Similarly, the same clinical study showed a superior 2-year survival rate for the subgroup of patients with bone marrow blast counts between 20 to $30 \%$ (that is, patients with AML according to current World Health Organization (WHO) criteria), with 2-year survival rates of 50 and $16 \%$ in the treatment and conventional group, respectively, and fewer days in hospital for the 5-AZA treatment group [61]. Based on its documented safety and efficiency, 5-AZA is an acceptable alternative for treatment of AML, at least in selected subsets of older patients.

\section{Biological and clinical effects of combining VPA and demethylating agents}

The epigenetic changes in AML include altered DNA methylation and histone acetylation leading to gene silencing. Several clinical studies have investigated the effect of combining VPA with DNA demethylating agents [62]. The results from five different studies are summarized in Table 3 [63-67]. Additional biological studies of these patients demonstrated that DNA hypomethylation and histone $\mathrm{H} 3 / \mathrm{H} 4$ acetylation can be induced by this treatment [66]. Taken together, these studies suggest that the toxicity of this regimen is acceptable even in older patients; encephalopathy/confusion has been described in a relatively high number of patients in certain studies, but this would be an expected dose-dependent effect of VPA. The studies of VPA plus ATRA in older patients suggests that it may be difficult to reach the ordinary therapeutic serum levels of VPA in these patients; however, relatively low serum levels may be sufficient for induction of an antileukemic response [51]. Taken together, these studies suggest that VPA plus a demethylating agent is more effective than combining VPA and ATRA. The results summarized 
Table 2 Valproic acid (VPA) and all-trans retinoic acid (ATRA) in the treatment of acute myeloid leukemia (AML): summary of clinical studies

\begin{tabular}{|c|c|c|c|c|c|c|}
\hline Study & $\begin{array}{l}\text { Number } \\
\text { of patients }\end{array}$ & $\begin{array}{l}\text { Median age } \\
\text { (range) (years) }\end{array}$ & Diagnosis & Treatment & Results & Common toxicity \\
\hline $\begin{array}{l}\text { Ryningen et al., } \\
2009 \text { [51] }\end{array}$ & 24 & 71 (47 to 86$)$ & AML & $\begin{array}{l}\text { ATRA } 22.5 \mathrm{mg} / \mathrm{m}^{2} \times 2 \text { day } 1 \text { to } 15 \text {. VPA and } \\
\text { theophylline iv day } 3 \text { to } 7 \text {, thereafter, orally } \\
\text { indefinitely. Serum levels of theophylline } 50 \\
\text { to } 100 \mu \mathrm{M} \text {, VPA } 200 \text { to } 700 \mu \mathrm{M} \text {. }\end{array}$ & $\begin{array}{l}\text { MDS criteria: } 9 / 22 \text { patients had increasing } \\
\text { cell counts and } 4 / 22 \text { patients (18\%) HI [52,53]. } \\
\text { Median survival } 64 \text { days ( } 7 \text { to } 644 \text { days). }\end{array}$ & $\begin{array}{l}\text { Two patients had atrial fibrillation. } \\
\text { Fatigue and nausea were most common. }\end{array}$ \\
\hline Bellos et al., 2008 [47] & 22 & 71.5 (41 to 89 ) & $\begin{array}{l}\text { AML }(95 \%) \\
\text { or MDS }\end{array}$ & $\begin{array}{l}\text { VPA } 150 \text { to } 300 \mathrm{mg} / \mathrm{d} \text {. ATRA } 45 \mathrm{mg} / \mathrm{m}^{2} / \mathrm{d} \\
\text { for } 14 \text { days. }\end{array}$ & $\begin{array}{l}\text { MDS criteria: four patients HI-P and one } \\
\text { patient HI-E. Treatment duration } 37 \text { days } \\
\text { ( } 4 \text { to } 730 \text { days). }\end{array}$ & $\begin{array}{l}\text { Usually well tolerated. Two patients had } \\
\text { ATRA syndrome and two patients had } \\
\text { continuous fever. }\end{array}$ \\
\hline $\begin{array}{l}\text { Cimino et al., } \\
2006[19]\end{array}$ & 8 & 61.5 (31 to 69$)$ & $\begin{array}{l}\text { AML (88\%) or } \\
\text { CML blast crisis }\end{array}$ & $\begin{array}{l}\text { VPA } 15 \text { to } 30 \mathrm{mg} / \mathrm{kg} / \mathrm{d} \text { with serum levels } \\
50 \text { to } 110 \mu \mathrm{mg} / \mathrm{ml} \text {. ATRA } 45 \mathrm{mg} / \mathrm{m}^{2} \text { from day } \\
\text { 14. Cytoreductive drugs if hyperleukocytosis. }\end{array}$ & $\begin{array}{l}\text { Two patients }(25 \%) \mathrm{H} \text { and five patients had } \\
\text { stable disease. No clinical response according } \\
\text { to AML criteria [54]. Survival } 119 \text { days } \\
\text { (60 to } 184 \text { days). }\end{array}$ & $\begin{array}{l}\text { One patient had grade III hepatic toxicity, } \\
\text { and one patient had vertigo and tremor. }\end{array}$ \\
\hline $\begin{array}{l}\text { Kuendgen et al., } \\
2006[40]\end{array}$ & 58 & 71 (42 to 86$)$ & AML & $\begin{array}{l}\text { VPA reaching serum levels } 50 \text { to } 100 \mathrm{\mu g} / \mathrm{ml} \text {. } \\
\text { ATRA either } 80 \mathrm{mg} / \mathrm{m}^{2} \text { days } 1 \text { to } 7 \text { every } \\
\text { second week, or ATRA } 15 \mathrm{mg} / \mathrm{m}^{2} / \mathrm{d} \text { from } \\
\text { day } 4 \text {. Total of } 31 \text { patients received VPA } \\
\text { monotherapy. Cytoreductive drugs if } \\
\text { hyperleukocytosis. }\end{array}$ & $\begin{array}{l}\text { AML criteria: one patient CR, one patient CRi } \\
\text { and one patient PR;5\% response. MDS criteria: } \\
16 \% \text { responses, } 34 \% \text { stable disease and } 50 \% \\
\text { progressive disease. No difference between } \\
\text { treatment groups. Median OS } 6.74 \text { months. }\end{array}$ & $\begin{array}{l}\text { Seven patients had tremors. Four patients } \\
\text { had grade } I / I l \text { skin toxicity, three patients } \\
\text { had grade } / / I l \text { gastrointestinal toxicity and } \\
\text { one patient had pleural effusion. }\end{array}$ \\
\hline Bug et al., 2005 [48] & 26 & 69 (59 to 84$)$ & $\begin{array}{l}\text { AML (92\%) or } \\
\text { advanced MDS }\end{array}$ & $\begin{array}{l}\text { VPA } 5 \text { to } 10 \mathrm{mg} / \mathrm{kg} / \mathrm{d} \text {, escalating doses to } 5 \\
\text { to } 64 \mathrm{mg} / \mathrm{kg} \text {. ATRA } 45 \mathrm{mg} / \mathrm{m}^{2} / \mathrm{d} \text {. } \\
\text { Cytoreductive drugs if hyperleukocytosis. }\end{array}$ & $\begin{array}{l}\text { One patient } P R \text {, one patient had minor } \\
\text { response }(2 / 19) \text { and no patients CR; } 10 \% \\
\text { responses. Survival not reported. }\end{array}$ & $\begin{array}{l}\text { Three patients had grade IV neurological } \\
\text { or pulmonary toxicity and there were } 21 \\
\text { events with grade III toxicity. }\end{array}$ \\
\hline $\begin{array}{l}\text { Raffoux et al., } \\
2005 \text { [50] }\end{array}$ & 11 & 82 (70 to 85$)$ & AML & $\begin{array}{l}\text { VPA reaching serum levels } 50 \text { to } 100 \mu \mathrm{gg} / \mathrm{ml} \text {. } \\
\text { ATRA } 45 \mathrm{mg} / \mathrm{m}^{2} / \mathrm{d} \text { from day } 7 \text {. Theophylline } \\
\text { reaching serum levels } 10 \text { to } 15 \mu \mathrm{g} / \mathrm{ml} \text {. } \\
\text { Cytoreductive drugs if hyperleukocytosis. }\end{array}$ & $\begin{array}{l}\text { AML criteria: one patient CR and two patients } \\
\text { CRi. According to MDS criteria: two additional } \\
\text { patients with HI. Survival } 6 \text { months ( } 1 \text { to } \\
28 \text { months). }\end{array}$ & $\begin{array}{l}\text { Main side effects were tremor, mental } \\
\text { confusion and theophylline-related } \\
\text { palpitations. }\end{array}$ \\
\hline $\begin{array}{l}\text { Kuendgen et al., } \\
2005 \text { [39] }\end{array}$ & 75 & 67 (21 to 84$)$ & $\begin{array}{l}\text { AML }(43 \%) \\
\text { or MDS }\end{array}$ & $\begin{array}{l}\text { VPA reaching serum concentrations } 50 \text { to } \\
100 \mathrm{\mu g} / \mathrm{ml} \text {. Total of } 66 \text { patients received } \\
\text { VPA monotherapy. ATRA } 80 \mathrm{mg} / \mathrm{m}^{2} \text { days } 1 \\
\text { to } 7 \text { every second week. }\end{array}$ & $\begin{array}{l}\text { MDS criteria: } 18 \text { patients responded ( } 24 \%) \text {, } \\
\text { one patient } C R \text {, one patient } \mathrm{PR}, 16 \text { patients } \\
\mathrm{HI} \text { and } 25 \text { patients had stable disease. } \\
\text { Median response duration } 4 \text { months } \\
\text { ( } 2 \text { to } 27 \text { months). }\end{array}$ & Skin and gastrointestinal toxicity. \\
\hline $\begin{array}{l}\text { Pilatrino et al., } \\
2005[49]\end{array}$ & 20 & 70 (63 to 80$)$ & $\begin{array}{l}\text { AML }(65 \%) \\
\text { or MDS }\end{array}$ & $\begin{array}{l}\text { VPA } 10 \mathrm{mg} / \mathrm{kg} / \mathrm{d} \text { escalating to } 311 \text { to } \\
693 \mu \mathrm{M} \text {. ATRA } 45 \mathrm{mg} / \mathrm{m}^{2} / \mathrm{d} \text {. Cytoreductive } \\
\text { drugs if hyperleukocytosis. }\end{array}$ & $\begin{array}{l}\text { MDS criteria: } 30 \% \text { patients } \mathrm{HI} \text { and no } \\
\text { patients CR. Median duration of response } \\
189 \text { days ( } 63 \text { to } 550 \text { days). }\end{array}$ & Neurologic toxicity and bone pain. \\
\hline
\end{tabular}

AML, acute myeloid leukemia; ATRA, all-trans retinoic acid; CML, chronic myeloid leukemia; CR, complete remission; CRi, complete remission incomplete (peripheral blood criteria not fulfilled); HI, hematological improvement; HI-E, hematological improvement in erythrocytes; HI-P, hematological improvement in platelet counts; MDS, myelodysplastic syndrome; OS, overall survival; PR, partial remission; VPA valproic acid. 
Table 3 Combination of histone deacetylase (HDAC) inhibition and demethylating agents: summary of clinical studies

\begin{tabular}{|c|c|c|c|c|c|c|}
\hline Study & $\begin{array}{l}\text { Number of } \\
\text { patients }\end{array}$ & $\begin{array}{l}\text { Median } \\
\text { age (years) }\end{array}$ & Diagnosis & Treatment & Results & Common toxicity \\
\hline Raffoux et al., 2010 [64] & 65 & 72 & $\begin{array}{l}\text { AML (85\%) or } \\
\text { high-risk MDS }\end{array}$ & $\begin{array}{l}\text { 5-AZA } 75 \mathrm{mg} / \mathrm{m}^{2} \text {. VPA } 35 \text { to } 50 \mathrm{mg} / \mathrm{kg} \\
\text { po day } 1 \text { to } 7 \text {. ATRA } 45 \mathrm{mg} / \mathrm{m}^{2} \text { po day } \\
8 \text { to } 28 \text {. Six cycles. }\end{array}$ & $\begin{array}{l}\text { After six cycles, } 34 \text { patients survived: } \\
13 \text { patients (38\%) CR, two patients (6\%) } \\
\text { PR and } 14 \text { patients (41\%) had stable } \\
\text { disease. Median OS was } 12.4 \text { months. }\end{array}$ & $\begin{array}{l}\text { Confusion } 33 \text { events, infection } \\
76 \text { events. }\end{array}$ \\
\hline Blum et al., 2007 [63] & 25 & 70 & AML & $\begin{array}{l}\text { Decitabine } 15 \text { to } 20 \mathrm{mg} / \mathrm{m}^{2} / \mathrm{d} \text { iv days } 1 \\
\text { to } 10 \text { every } 28 \text { days. VPA } 15 \text { to } 20 \mathrm{mg} / \mathrm{kg} \\
\text { days } 5 \text { to } 21 \text { in ten patients. }\end{array}$ & $\begin{array}{l}\text { Response rate was } 44 \% \text { : four patients } \\
\text { CR, four patients CRi and three patients } \\
\text { PR (AML criteria). Survival not reported. }\end{array}$ & $\begin{array}{l}\text { Neutropenic fever (64\%), fatigue } \\
\text { and infection (both 48\%) were } \\
\text { most common. }\end{array}$ \\
\hline Soriano et al., 2007 [65] & 53 & 69 & $\begin{array}{l}\text { AML }(92 \%) \text { or } \\
\text { high-risk MDS }\end{array}$ & $\begin{array}{l}\text { 5-AZA } 75 \mathrm{mg} / \mathrm{m}^{2} / \mathrm{d} \text {. VPA } 50 \text { to } 75 \mathrm{mg} / \mathrm{kg} / \mathrm{d} \\
\text { days } 1 \text { to } 7 \text {. ATRA } 45 \mathrm{mg} / \mathrm{m}^{2} \text { days } 3 \text { to } 5 \text {. } \\
\text { Treatment repeated every } 3 \text { weeks. }\end{array}$ & $\begin{array}{l}\text { Overall response rate was } 42 \%: 12 \\
\text { patients (22\%) CR. Survival not reported. }\end{array}$ & $\begin{array}{l}\text { Two events of grade IV and } 11 \\
\text { events of grade III } \\
\text { non-hematological toxicity; } \\
\text { mainly fatigue or other } \\
\text { neurotoxicities. }\end{array}$ \\
\hline Garcia-Manero et al., 2006 [66] & 54 & 60 & $\begin{array}{l}\text { AML }(89 \%) \\
\text { or MDS }\end{array}$ & $\begin{array}{l}\text { Decitabine } 15 \mathrm{mg} / \mathrm{m}^{2} / \mathrm{d} \text { iv. VPA } 20 \text { to } \\
50 \mathrm{mg} / \mathrm{kg} \text { days } 1 \text { to } 10 \text {. Treatment } \\
\text { repeated every fourth week. }\end{array}$ & $\begin{array}{l}\text { Twelve patients (22\%) had responses: } \\
10 \text { patients CR and two patients CRp. } \\
\text { OS } 6 \text { months ( } 0.6 \text { to } 20.2 \text { months). }\end{array}$ & $\begin{array}{l}\text { Fatigue, nausea and diarrhoea } \\
\text { were the most common } \\
\text { non-hematological toxicities. }\end{array}$ \\
\hline Maslak et al., 2006 [67] & 10 & 66.5 & $\begin{array}{l}\text { AML }(80 \%) \\
\text { or MDS }\end{array}$ & $\begin{array}{l}\text { 5-AZA } 75 \mathrm{mg} / \mathrm{m}^{2} / \mathrm{d} \text { days } 1 \text { to } 7 \text {. Sodium } \\
\text { phenylbutyrate } 200 \mathrm{mg} / \mathrm{kg} / \mathrm{d} \text { iv days } 8 \\
\text { to } 12 . \text { Treatment repeated every } 21 \text { to } \\
28 \text { days. }\end{array}$ & $\begin{array}{l}\text { Three patients (30\%) PR and two } \\
\text { patients (20\%) had stable disease. } \\
\text { Duration of response was } 45 \text { days } \\
\text { (37 to } 136 \text { days). Survival not reported. }\end{array}$ & $\begin{array}{l}\text { Three patients had neutropenic } \\
\text { fever. Nausea, dizziness and } \\
\text { fatigue were common. }\end{array}$ \\
\hline
\end{tabular}

5-AZA, 5-azacytidine; AML, acute myeloid leukemia; ATRA, all-trans retinoic acid; CR, complete
MDS, myelodysplastic syndrome; OS, overall survival; PR, partial remission VPA, valproic acid. 
in Tables 2 and 3 demonstrate that the OS and CR rates are generally better for patients treated with VPA plus demethylating agent. However, with the lack of randomized clinical studies it is not possible to make a firm conclusion about the preferred regimen combination.

\section{VPA versus other histone deacetylase (HDAC) inhibitors in the treatment of human AML}

Except for VPA, several other HDAC inhibitors have been developed, as described in a recent review article [14], and used in clinical studies [68,69]. In 2007, vorinostat was the first HDAC inhibitor to be approved as treatment for the malignant disease primary cutaneous $\mathrm{T}$ cell lymphoma. Phase I and phase II studies in AML have been undertaken combining vorinostat with demethylating agents or chemotherapy. The response rates have varied between 4 to $86 \%$ with combined treatment showing the best results [70-74]. Mocetinostat (MGCD0103) has shown response rates from 10 to $30 \%$ with best results when combined with 5-AZA [14]. Entinostat was also combined with 5-AZA and showed a response rate of $44 \%$ in 31 patients, including $7.5 \% \mathrm{CR}$, whereas a monotherapy phase I trial showed no responses [14]. Panobinostat (LBH-589) and romidepsin have also been developed, and they showed no response in phase I trials as monotherapy for different types of leukemia and MDS in 15 and 20 patients, respectively [14]. Other HDAC inhibitors have been developed but data are still preliminary. As for VPA, it is essential to also combine these HDAC inhibitors with other active substances to increase the response rates. Finally, butyrate is still considered as a therapeutic tool in clinical oncology [75], but, as previously reviewed, the results from available clinical studies in hematological malignancies are not promising [76,77].

To conclude, VPA is still the best investigated HDAC inhibitor for the treatment of human AML, both with regard to low-toxicity disease-stabilizing treatment and more intensive remission-inducing treatment.

\section{Low-toxicity treatment with cytotoxic drugs: an alternative to VPA or a possibility of combination therapy?}

Several clinical reports have described the combined use of VPA with low-toxicity conventional chemotherapy. As described below, VPA has been combined with cytarabine, hydroxyurea and 6-mercaptopurine (6-MP); three drugs that interact with nucleic acid synthesis through targeting of different intracellular molecules.

\section{Low-dose cytarabine}

Cytarabine is an analogue of deoxycytidine and shares the same metabolic pathway as this deoxycytidine [78]. Cytarabine is metabolized to its active triphosphate form, which inhibits the enzyme DNA polymerase alpha and is incorporated into elongating DNA strands, thereby causing chain termination. However, this triphosphate form is degraded by several enzymes and this intracellular metabolism is also regulated by several feedback mechanisms. The cytarabine-mediated cytotoxicity caused by its active triphosphate form is thereby determined by a complex interplay between cytarabine dose, anabolism, catabolism, and endogenous purine and pyrimidine levels [78].

Cytarabine is a cornerstone of AML treatment [79]. In 1987, treatment with low-dose subcutaneous cytarabine in 129 AML patients resulted in a CR rate of $31 \%$ and PR rate of $18 \%$ [80]. Later, low-dose cytarabine was combined with various therapeutic agents, including other cytotoxic drugs, growth factors, arsenic trioxide and homoharringtonine [81-84]. In these four trials, the CR rates were 14 to $52 \%$ and the cytarabine dose varied between 15 to $20 \mathrm{mg} / \mathrm{m}^{2} / \mathrm{d}$ for 10 to 14 days. Although low-dose cytarabine is frequently used, the mechanism of action is not known in detail and may include differentiation induction, as well as direct cytotoxic effects [85].

The biological effects and clinical results of low-dose cytarabine have been recently reviewed [85]. The following conclusions can be made based on the currently available clinical studies in human AML: 1) the treatment has an antileukemic effect and can improve survival; 2) the treatment is most effective for patients with low- and intermediate-risk disease, and the improved survival is mainly due to a beneficial effect in a minority of patients achieving complete hematological remission; 3) survival is not improved for patients with high-risk cytogenetic abnormalities; 4) the cytarabine dose used in these studies varies between 10 and $40 \mathrm{mg} / \mathrm{m}^{2}$ given once or twice daily, and the duration of treatment is usually 10 days but up to 21 days has been used; 5) treatment-related mortality is seen at least when using the higher doses, but this mortality shows a wide variation between studies; and 6) combination with other cytotoxic drugs is possible, but this has been investigated mainly in very small clinical studies and some of these studies suggest that the treatment-related mortality will then be increased.

Although effective, a major drawback of subcutaneous cytarabine is that patients often have to attend the outpatient department to receive the subcutaneous injections.

\section{Hydroxyurea}

DNA synthesis requires production of deoxyribonucleotides and ribonucleotide reductase is necessary for this production [86]. Hydroxyurea inactivates the enzyme directly through electron donation but also indirectly through conversion to nitric oxide. This enzyme is also necessary for DNA repair and causes a block at the G1/S transition of the cell cycle, and thereby has cytotoxic effects.

Hydroxyurea has been used for decades in the treatment of hematologic malignancies; its activity is based on inhibition of the ribonucleotide reductase enzyme, and thereby 
inhibition of DNA synthesis [87]. Despite the lack of supporting clinical data, hydroxyurea is often used in AML for older patients not eligible for intensive chemotherapy. In a retrospective analysis of 244 older patients, $52 \%$ of patients received hydroxyurea and no significant difference in survival compared to treatment with 6-thioguanine (6-TG) or low-dose cytarabine was found [88]. A recent randomized clinical trial showed that low-dose cytarabine was superior to hydroxyurea in 217 older patients [89], resulting in CR rates of $18 \%$ versus $1 \%$, respectively. In this study, the cytarabine dose was standardized to $20 \mathrm{mg} / \mathrm{m}^{2}$ twice daily for 10 days every 4 to 6 weeks, whereas hydroxyurea was administered to keep the white blood cell count below $10 \times 10^{9} / 1$. The addition of ATRA made no significant difference. Another small study showed acceptable safety and a CR rate of $41.6 \%$ for high-dose hydroxyurea $(100 \mathrm{mg} / \mathrm{kg} / \mathrm{d})$ administered daily until bone marrow aplasia, or for a maximum of 30 days for 12 patients with poor-risk AML [90].

\section{6-mercaptopurine (6-MP)}

6-MP is a thiopurine and an analog of hypoxanthine [91,92]. The mechanism for its cytotoxic activity seems to be intracellular conversion to 6-TG nucleotides and methylated derivatives, which have a cytotoxic effect. Several molecular mechanisms may contribute to this effect, including incorporation of 6-TG nucleotides into nucleic acids. The drug has been used in AML therapy, mainly in palliative or maintenance treatment $[93,94]$. In Japanese trials, the drug was used at the dose of $70 \mathrm{mg} / \mathrm{m}^{2}$ for 7 days in repetitive cycles. A major advantage of both hydroxyurea and 6-MP is the oral administration, which makes management of outpatients easier.

\section{The possibility to combine VPA with low-toxicity cytotoxic therapy}

Clinical studies have shown that VPA, possibly together with ATRA, can be combined with low-dose cytarabine $[20,95,96]$, hydroxyurea and 6-MP $[23,95]$. The results from the first three studies of VPA plus low-dose cytarabine are conflicting. One study concluded that the combination had limited clinical effect [96], while induction of CR was seen in the two other studies $[20,95]$. The largest study included 36 patients treated with continuous administration of VPA, intermittent oral ATRA $\left(21.5 \mathrm{mg} / \mathrm{m}^{2}\right.$ for 14 days every third month) and subcutaneous cytarabine $\left(10 \mathrm{mg} / \mathrm{m}^{2}\right.$ once daily for 10 days every third month) [95]. If cytarabine could not control hyperleukocytosis, it was replaced by hydroxyurea or 6-MP to maintain the peripheral blood blast count below $50 \times 10^{9} / 1$ and to avoid symptoms of leukostasis [97]. In this study, the median age of the patients was 77 years (range 48 to 90 years), 11 patients responded to the treatment according to the MDS response criteria and two of these patients achieved complete hematological remission. The responders had a median survival of 171 days (range 102 to $>574$ days) and most of this time was spent outside hospital. These results suggest that a subset of patients will benefit from this treatment, and this is supported by a third study [20].

Experimental studies suggest that VPA may also be combined with other therapeutic agents in the treatment of human AML [98-109]. These results are summarized in Table 4.

\section{Best supportive care versus disease-stabilizing treatment based on VPA in unfit AML patients: should VPA be recommended even though randomized clinical trials are not available?}

Best supportive care in AML generally refers to treatment with antibiotics and transfusions of blood products. Low-intensity therapy is often offered to control leukocytosis [110]. Retrospective analyses of a group of 244 AML patients not fit for standard treatment, but with $72.5 \%$ of patients receiving hydroxyurea, low-dose cytarabine or 6-TG, showed a median OS of 178 days (range 1 to 3,278) [88]. Eighty per cent of patients survived less than 12 months. Another retrospective study, including 2,657 AML patients older than 65 years, showed that $86 \%$ of patients died within 1 year [111]. Median OS was 2 months, ranging from 1 month for patients aged 85 years and older, to 3 months for patients aged 65 to 74 years. In this last study, $30 \%$ of patients received low-toxicity chemotherapy and the average age of these patients was 73 years, whereas the average age of the whole group was 77 years. Median OS for treated patients was 6 months longer than for the untreated patients, regardless of age at the time of diagnosis [111]. Similarly, a systematic review of clinical studies published between 1989 and 2006, including a total of 12,370 AML patients with median age 70 years, showed a median OS for patients receiving best supportive care of only 7.5 weeks [112]. Approximately 50\% of these patients received intensive induction therapy, $30 \%$ received non-intensive chemotherapy and 20\% received best supportive care.

These studies clearly demonstrate that unfit AML patients only receiving supportive care usually have a very short survival. Disease-stabilizing treatment based on VPA offers an opportunity of improved peripheral blood cell counts, to such a degree that the risk of bleeding or infections and the need for erythrocyte transfusions is reduced, compared with the pre-therapy situation. Is it then justified to recommend VPA-based treatment to these patients in the absence of randomized clinical studies, or should they still receive only supportive treatment? In our opinion, the answer is that VPAbased treatment should be recommended, because: 1) 
Table 4 Possible combinations of valproic acid (VPA) with other therapeutic agents: current experimental evidence

\begin{tabular}{|c|c|c|}
\hline Agent & Evidence & Study \\
\hline Curcumin & $\begin{array}{l}\text { Curcumin is a natural anticancer agent that affects the expression of NF-KB, } \\
\text { Bcl- } 2 \text { and Bax in leukemic cells. The combination with VPA causes upregulation } \\
\text { of Bax with proliferation arrest, sub-G1 DNA accumulation and cell death in } \\
\text { the HL-60 AML cell line. The effect is dependent on p38 activation. }\end{array}$ & Chen et al., 2010 [100] \\
\hline Folate receptor beta & $\begin{array}{l}\text { The folate receptor beta mediates antiproliferative effects in AML cells and } \\
\text { VPA upregulates the expression of this receptor. VPA and ATRA, combined } \\
\text { with targeting of this receptor, may therefore have additive or synergistic } \\
\text { antileukemic effects. }\end{array}$ & Qi and Ratnam, 2006 [105] \\
\hline HSP90 inhibition & $\begin{array}{l}\text { Co-treatment of the AML1/ETO-expressing Kasumi-1 cell line with VPA and } \\
\text { the HSP90 inhibitor 17-AAG causes a synergistic inhibition of downstream } \\
\text { signaling of mutated c-KIT. }\end{array}$ & Yu et al., 2011 [108] \\
\hline Hydralazine & $\begin{array}{l}\text { Hydralazine is a nontoxic agent with DNA MTase-inhibiting effects. A clinical } \\
\text { study suggested that the combination of hydralazine and VPA was a nontoxic } \\
\text { treatment with an antileukemic effect in vivo. The effect has not been } \\
\text { compared with VPA in combination with decitabine or 5-AZA. }\end{array}$ & Candelaria et al., 2011 [99] \\
\hline mTOR inhibition & $\begin{array}{l}\text { Studies in AML cell lines show no additive proapoptotic effects, but only a } \\
\text { limited number of cell lines were examined. However, in other experimental } \\
\text { models of Flt3-ITD-transformed cells, VPA and mTOR inhibitors had synergistic } \\
\text { proapoptotic effects. }\end{array}$ & $\begin{array}{l}\text { Cai et al., } 2006 \text { [98]; Ryningen } \\
\text { et al., } 2012 \text { [106] }\end{array}$ \\
\hline NF-kB inhibition & $\begin{array}{l}\text { Experimental studies suggest that the antileukemic effect of DNA MTase and } \\
\text { HDAC inhibition is not only caused by epigenetic mechanisms, but also by } \\
\text { additional and independent inhibition of NF-kB. Specific NF-kB inhibitors are } \\
\text { now being developed and the antileukemic effects of proteasome inhibitors } \\
\text { are also most likely caused by NF-KB inhibition. }\end{array}$ & Fabre et al., 2008 [101] \\
\hline p53 agonism, nutlin & $\begin{array}{l}\text { The p53 agonist nutlin was combined with VPA, and the two drugs caused a } \\
\text { synergistic induction of p53-dependent apoptosis in AML cell lines and } \\
\text { primary AML cells. This synergism was also demonstrated in xenograft models } \\
\text { of human AML. }\end{array}$ & McCormack et al., 2012 [103] \\
\hline $\begin{array}{l}\text { Proteasome inhibitors, } \\
\text { including bortezomib }\end{array}$ & $\begin{array}{l}\text { This combination has an antiproliferative effect with cell cycle arrest of AML } \\
\text { cell lines. Apoptosis is induced through caspase activation, and inhibition of } \\
\text { cyclin D and telomerase is induced. The two drugs have synergistic effects. } \\
\text { This synergism is also seen for other proteasome inhibitors, and, at least in } \\
\text { certain experiments, the antileukemic effect is stronger for the proteasome } \\
\text { inhibitors NPI-0051 and PR-171 than for bortezomib. }\end{array}$ & $\begin{array}{l}\text { Fuchs et al., } 2009 \text { [102]; Nie et al., } \\
2012 \text { [104]; Wang et al., } 2011 \text { [107] }\end{array}$ \\
\hline sTRAIL & $\begin{array}{l}\text { When VPA was combined with an anti-CD33 single chain fragment linked } \\
\text { to sTRAIL, the two agents had synergistic effects on apoptosis induction in } \\
\text { primary human AML cells. }\end{array}$ & ten Cate et al., 2009 [109] \\
\hline
\end{tabular}

17-AAG, 17-N-allylamino-17-demethoxygeldanamycin; 5-AZA, 5-azacytidine; AML, acute myeloid leukemia; ATRA, all-trans retinoic acid; Bax, Bcl-2-associated X protein; Bcl-2, B-cell lymphoma 2; DNA MTase, DNA methyltransferase; HDAC, histone deacetylase; HSP90, heat shock protein 90; ITD, internal tandem duplications; mTOR, mammalian target of rapamycin; NF-KB, nuclear factor kappa-light-chain-enhancer of activated B cells; sTRAIL, soluble tumor necrosis factor-related apoptosis-inducing ligand; VPA, valproic acid.

improved normal cell counts is an advantage that will reduce the risk of potentially severe complications; 2 ) all available studies suggest that this advantage can be achieved with acceptable toxicity; and 3) the low-toxicity justifies that this treatment is used for a period of several weeks even though the response rate is less than $50 \%$.

\section{Future perspectives: the development of VPA as an antileukemic agent \\ Autologous antileukemic immune reactivity: experimental artefact or clinical reality?}

The strategy to use tumor-specific vaccines as an individualized treatment was suggested several decades ago [113], and in vivo experiments in mice have supported this strategy [114]. However, whether enhancement of antileukemic immune reactivity is possible in humans (for example through vaccination with AML-associated antigens) requires further study. The use of such an approach as a low-toxicity strategy in older patients is supported by several observations. First, primary human AML cells can undergo immunogenic apoptosis with exposure of calreticulin, and release heat shock protein 70 (HSP70) and heat shock protein 90 (HSP90); this may initiate or enhance the development of antileukemic $\mathrm{T}$ cell reactivity [115]. Second, a prognostic impact of serum heat shock protein (HSP) levels has been suggested [116-119], possibly caused by soluble HSPs that facilitate immunogenic presentation of the client proteins. Finally, our recent study demonstrated that AML patients are heterogeneous with regard to systemic levels of immunoregulatory cytokines and patients could be subclassified based on their serum cytokine profiles; the effect of 
immunotherapy may therefore vary between patient subsets [22]. Thus, the possibility to enhance autologous antileukemic immune reactivity should be studied further as a low-toxicity treatment in human AML, and this strategy should combine with antileukemic chemotherapy [120]. Immunological side effects should be evaluated in future clinical studies of VPA treatment in human AML.

\section{What are the response criteria for studies of AML-stabilizing therapy?}

The MDS response criteria developed by the International Working Group (IWG) for MDS [52,53] have been used to describe the effects of AML patients receiving disease-stabilizing treatment. The alternative IWG criteria for response in AML [54] are developed for AML patients treated with intensive chemotherapy, with the intention to induce complete hematological remission. However, with a palliative treatment strategy, minor hematological improvement or disease stabilization are also important in AML. Furthermore, the question of duration of the response is important in the MDS criteria. Duration of the response is certainly important for AML patients receiving diseasestabilizing therapy, but the durations are generally expected to be shorter in disease-stabilizing treatment of highly aggressive AML than for MDS patients with a much longer expected survival even without disease-directed therapy. Responses of shorter duration would therefore be of biological as well as clinical relevance in patients with AML. Complete hematological remission of any duration is important and may lead to longer survival even in patients receiving low-intensive treatment [54]. However, the MDS criteria are more detailed and provide the best opportunity to describe minor responses more accurately.

In a previous study exploring the combination of VPA, ATRA and theophylline in unfit AML patients, increased normal peripheral blood cell counts were also described for patients who did not fulfill the criteria for hematological improvement, as defined by the MDS criteria [51]. In this study, improvements of platelet levels, increased neutrophil or reticulocyte counts, or transfusion independency of durations shorter than 8 weeks, were reported. This is an alternative way of describing minor responses during palliative treatment in AML. Reporting of such small responses is justified because AML is usually a rapidly progressive disease and any spontaneous improvement is regarded as unexpected. However, the best solution would be to gain a general agreement on specific response criteria for patients receiving AML-stabilizing therapy.

\section{How should quality of life (QoL) be evaluated in early clinical trials?}

Quality of life (QoL) is reduced in AML patients particularly at the time of diagnosis, due to the symptoms and signs of the disease, the information about the diagnosis and prognosis, and the initial treatment, but it usually improves and stabilizes [121,122]. There is no difference in QoL in older AML patients receiving intensive or non-intensive treatment when comparing the pretreatment basic values, and the values after diagnosis and during treatment $[123,124]$. Different instruments and questionnaires are used to quantitatively measure QoL in AML, as well as in other hematologic malignancies, but the European Organization for Research and Treatment of Cancer (EORTC) QLQ-C30 questionnaire is one of the most commonly used scientific tools [121-123]. Evaluation of QoL is often not included in early phase II studies, but is important in larger randomized trials. An alternative for phase II studies is to report parameters, such as time in hospital versus days at home, to describe the situation of the patients, and such factors are most likely important for the patients' QoL. Since previous studies have shown that QoL is related to response to therapy [125], it is likely that treatment-induced disease stabilization or even remission induction due to low-intensity treatment would lead to an improvement in QoL.

\section{Review and conclusion}

Epigenetic strategies in AML are regarded as promising. The detection of reversible epigenetic changes reflected in the chromatin structure has increased our understanding of leukemia development and identified new therapeutic targets [126-128]. In addition to clinical trials with HDAC inhibitors, the number of trials with demethylating agents is also increasing and the combination of these two epigenetic strategies seem to have synergistic effects $[129,130]$ (Table 3). HDAC inhibitor monotherapy has limited effects in AML and this treatment should be combined with other antileukemic agents in future clinical studies $[39,40]$. Particularly in the treatment of older AML patients, new targeted therapies should be tried and epigenetic strategies then represent well tolerated alternatives. Further increase of response rates can hopefully be made through development of low-toxicity combination therapy. Thus, in future, HDAC inhibitors should form part of the AML treatment, at least for older patients or patients unfit for intensive chemotherapy. A future role of VPA in the treatment of myeloproliferative diseases, including AML, is also supported by recent observations suggesting that this agent may be useful in chronic myeloproliferative neoplasms [131,132].

The available studies of VPA therapy in human AML have demonstrated that HDAC inhibition is a therapeutic strategy that should be investigated further. Future clinical studies should address the question of whether VPA, or any other drugs, should be the preferred HDAC inhibitor and investigate the optimal drug(s) to combine with HDAC inhibition. Randomized clinical trials are also needed to compare HDAC inhibition with alternative therapeutic 
approaches. HDAC inhibition as a therapeutic strategy should be considered, particularly in patients unfit for more intensive chemotherapy. This view is based on the available results from several clinical studies, which shows that VPA is the HDAC inhibitor most extensively investigated in human AML, this treatment can induce a clinically relevant improvement in peripheral blood cell counts and stabilization of the clinical status for a subset of AML patients, and the risk of clinically relevant toxicity is minimal.

\section{Abbreviations}

17-AAG: 17-N-allylamino-17-demethoxygeldanamycin; 5-AZA: 5-azacytidine; 6-MP: 6-mercaptopurine; 6-TG: 6-thioguanine; AML: Acute myeloid leukemia; APL: Acute promyelocytic leukemia; ATRA: All-trans retinoic acid; Bax: BCl-2-associated X protein; BCl-2: B-cell lymphoma 2; CML: Chronic myeloid leukemia; CR: Complete remission; CRi: Complete remission incomplete (peripheral blood criteria not fulfilled); CRp: Incomplete platelet recovery; CXCR-4: C-X-C chemokine receptor type 4; DNA MTase: DNA methyltransferase; EORTC: European Organization for Research and Treatment of Cancer; FOSB: FBJ murine osteosarcoma viral oncogene homolog B; HDAC: Histone deacetylase; HI: Hematological improvement; HI-E: Hematological improvement in erythrocytes; HI-P: Hematological improvement in platelet counts; HSP: Heat shock protein; HSP70: Heat shock protein 70; HSP90: Heat shock protein 90; HSP90AA1: Heat shock protein $90 \mathrm{kDa}$ alpha (cytosolic), class A member 1; HSP90AB1: Heat shock protein $90 \mathrm{kDa}$ alpha (cytosolic), class B member 1; ITD: Internal tandem duplications; iv: Intravenous; IWG: International Working Group; LBH-589: Panobinostat; MAPKAPK2: Mitogen-activated protein kinase-activated protein kinase 2; MDS: Myelodysplastic syndrome; MGCD0103: Mocetinostat;

mTOR: Mammalian target of rapamycin; NF-kB: Nuclear factor kappa-lightchain-enhancer of activated B cells; NK: Natural killer; OS: Overall survival; PML: Promyelocytic leukemia; po: Per os; PR: Partial remission; QoL: Quality of life; RARa: Retinoic acid receptor a; sTRAIL: Soluble tumor necrosis factor-related apoptosis-inducing ligand; UTX: Ubiquitously transcribed tetratricopeptide repeat, $X$ chromosome; VPA: Valproic acid; WHO: World Health Organization.

\section{Competing interests}

The authors declare that they have no competing interests.

\section{Authors' contributions}

$H F, B T G$ and $\varnothing B$ contributed to the writing of the article. All authors read and approved the final manuscript.

\section{Acknowledgements}

The Norwegian Cancer Society, Oslo, Norway, supports the scientific work of all authors.

\section{Author details}

${ }^{1}$ Section for Hematology, Institute of Medicine, University of Bergen, N-5021, Bergen, Norway. ${ }^{2}$ Department of Medicine, Haukeland University Hospital, Jonas Lies 65, 5021, Bergen, Norway.

Received: 5 March 2013 Accepted: 3 July 2013

Published: 30 July 2013

\section{References}

1. Estey E, Döhner H: Acute myeloid leukaemia. Lancet 2006, 368:1894-1907.

2. Büchner T, Berdel WE, Haferlach C, Haferlach T, Schnittger S, Müller-Tidow C, Braess J, Spiekermann K, Kienast J, Staib P, Grüneisen A, Kern W, Reichle A, Maschmeyer G, Aul C, Lengfelder E, Sauerland MC, Heinecke A, Wörmann B, Hiddemann W: Age-related risk profile and chemotherapy dose response in acute myeloid leukemia: a study by the German Acute Myeloid Leukemia Cooperative Group. J Clin Oncol 2009, 27:61-69.

3. Burnett $A$, Wetzler $M$, Löwenberg B: Therapeutic advances in acute myeloid leukemia. J Clin Oncol 2011, 29:487-494.

4. Cornelissen JJ, Gratwohl A, Schlenk RF, Sierra J, Bornhäuser M, Juliusson G, Råcil Z, Rowe JM, Russell N, Mohty M, Löwenberg B, Socié G, Niederwieser D, Ossenkoppele GJ: The European LeukemiaNet AML Working Party consensus statement on allogeneic HSCT for patients with AML in remission: an integrated-risk adapted approach.Nat Rev. Clin Oncol 2012, 9:579-590.

5. Appelbaum FR, Gundacker H, Head DR, Slovak ML, Willman CL, Godwin JE, Anderson JE, Petersdorf SH: Age and acute myeloid leukemia. Blood 2006, 107:3481-3485.

6. Kantarjian H, Ravandi F, O'Brien S, Cortes J, Faderl S, Garcia-Manero G, Jabbour E, Wierda W, Kadia T, Pierce S, Shan J, Keating M, Freireich EJ: Intensive chemotherapy does not benefit most older patients (age 70 years or older) with acute myeloid leukemia. Blood 2010, 116:4422-4429.

7. Giles FJ, Borthakur G, Ravandi F, Faderl S, Verstovsek S, Thomas D, Wierda W Ferrajoli A, Kornblau S, Pierce S, Albitar M, Cortes J, Kantarjian H: The haematopoietic cell transplantation comorbidity index score is predictive of early death and survival in patients over 60 years of age receiving induction therapy for acute myeloid leukaemia. $\mathrm{Br} J$ Haematol 2007, 136:624-627

8. Juliusson G, Antunovic P, Derolf A, Lehmann S, Möllgård L, Stockelberg D, Tidefelt U, Wahlin A, Höglund M: Age and acute myeloid leukemia: real world data on decision to treat and outcomes from the Swedish Acute Leukemia Registry. Blood 2009, 113:4179-4187.

9. Walter RB, Othus M, Borthakur G, Ravandi F, Cortes JE, Pierce SA, Appelbaum FR, Kantarjian HA, Estey EH: Prediction of early death after induction therapy for newly diagnosed acute myeloid leukemia with pretreatment risk scores: a novel paradigm for treatment assignment. J Clin Oncol 2011, 29:4417-4423.

10. Delcuve GP, Khan DH, Davie JR: Roles of histone deacetylases in epigenetic regulation: emerging paradigms from studies with inhibitors. Clin Epigenetics 2012, 4:5.

11. Kuendgen A, Gattermann N: Valproic acid for the treatment of myeloid malignancies. Cancer 2007, 110:943-954.

12. Blaheta RA, Nau H, Michaelis M, Cinatl J Jr: Valproate and valproate-analogues: potent tools to fight against cancer. Curr Med Chem 2002, 9:1417-1433.

13. Göttlicher M, Minucci S, Zhu P, Krämer OH, Schimpf A, Giavara S, Sleeman JP, Lo Coco F, Nervi C, Pelicci PG, Heinzel T: Valproic acid defines a novel class of HDAC inhibitors inducing differentiation of transformed cells. EMBO J 2001, 20:6969-6978.

14. Quintás-Cardama A, Santos FP, Garcia-Manero G: Histone deacetylase inhibitors for the treatment of myelodysplastic syndrome and acute myeloid leukemia. Leukemia 2011, 25:226-235.

15. Tickenbrock L, Klein HU, Trento C, Hascher A, Göllner S, Bäumer N, Kuss R, Agrawal S, Bug G, Serve H, Thiede C, Ehninger G, Stadt UZ, McClelland M, Wang Y, Becker A, Koschmieder S, Berdel WE, Dugas M, Müller-Tidow C, Study Alliance Leukemia Group: Increased HDAC1 deposition at hematopoietic promoters in AML and its association with patient survival. Leuk Res 2011, 35:620-625

16. Bradbury CA, Khanim FL, Hayden R, Bunce CM, White DA, Drayson MT Craddock C, Turner BM: Histone deacetylases in acute myeloid leukaemia show a distinctive pattern of expression that changes selectively in response to deacetylase inhibitors. Leukemia 2005, 19:1751-1759.

17. Bug G, Schwarz K, Schoch C, Kampfmann M, Henschler R, Hoelzer D, Ottmann OG, Ruthardt M: Effect of histone deacetylase inhibitor valproic acid on progenitor cells of acute myeloid leukemia. Haematologica 2007, 92:542-545.

18. Cheng YC, Lin H, Huang MJ, Chow JM, Lin S, Liu HE: Downregulation of c-Myc is critical for valproic acid-induced growth arrest and myeloid differentiation of acute myeloid leukemia. Leuk Res 2007, 31:1403-1411.

19. Cimino G, Lo-Coco F, Fenu S, Travaglini L, Finolezzi E, Mancini M, Nanni M, Careddu A, Fazi F, Padula F, Fiorini R, Spiriti MA, Petti MC, Venditti A, Amadori $S$, Mandelli F, Pelicci PG, Nervi C: Sequential valproic acid/all-trans retinoic acid treatment reprograms differentiation in refractory and high-risk acute myeloid leukemia. Cancer Res 2006, 66:8903-8911.

20. Corsetti MT, Salvi F, Perticone S, Baraldi A, De Paoli L, Gatto S, Pietrasanta D, Pini M, Primon V, Zallio F, Tonso A, Alvaro MG, Ciravegna G, Levis A: Hematologic improvement and response in elderly AML/RAEB patients treated with valproic acid and low-dose Ara-C. Leuk Res 2011, 35:991-997.

21. Forthun RB, Sengupta T, Skjeldam HK, Lindvall JM, McCormack E, Gjertsen BT, Nilsen $\mathrm{H}$ : Cross-species functional genomic analysis identifies resistance genes of the histone deacetylase inhibitor valproic acid. PLoS One 2012, 7:e48992.

22. Fredly H, Reikvam H, Gjertsen BT, Bruserud O: Disease-stabilizing treatment with all-trans retinoic acid and valproic acid in acute myeloid leukemia: Serum hsp70 and hsp90 levels and serum cytokine profiles are determined by the disease, patient age, and anti-leukemic treatment. Am J Hematol 2012, 87:368-376. 
23. Fredly H, Stapnes Bjørnsen C, Gjertsen BT, Bruserud Ø: Combination of the histone deacetylase inhibitor valproic acid with oral hydroxyurea or 6-mercaptopurin can be safe and effective in patients with advanced acute myeloid leukaemia--a report of five case. Hematology 2010, 15:338-343.

24. Goodyear O, Agathanggelou A, Novitzky-Basso I, Siddique S, McSkeane T, Ryan G, Vyas P, Cavenagh J, Stankovic T, Moss P, Craddock C: Induction of a CD8+ T-cell response to the MAGE cancer testis antigen by combined treatment with azacitidine and sodium valproate in patients with acute myeloid leukemia and myelodysplasia. Blood 2010, 116:1908-1918.

25. Gul H, Marquez-Curtis LA, Jahroudi N, Larratt LM, Janowska-Wieczorek A: Valproic acid exerts differential effects on CXCR4 expression in leukemic cells. Leuk Res 2010, 34:235-242.

26. Hauswald S, Duque-Afonso J, Wagner MM, Schertl FM, Lubbert M, Peschel C, Keller U, Licht T: Histone deacetylase inhibitors induce a very broad, pleiotropic anticancer drug resistance phenotype in acute myeloid leukemia cells by modulation of multiple $A B C$ transporter genes. Clin Cancer Res 2009, 15:3705-3715.

27. lacomino G, Medici MC, Russo GL: Valproic acid sensitizes K562 erythroleukemia cells to TRAIL/Apo2L-induced apoptosis. Anticancer Res 2008, 28:855-864.

28. Khanim FL, Bradbury CA, Arrazi J, Hayden RE, Rye A, Basu S, MacWhannell A, Sawers A, Griffiths M, Cook M, Freeman S, Nightingale KP, Grimwade D, Falciani F, Turner BM, Bunce CM, Craddock C: Elevated FOSB-expression; a potential marker of valproate sensitivity in AML. Br J Haematol 2009, 144:332-341.

29. Langenkamp U, Siegler U, Jörger S, Diermayr S, Gratwohl A, Kalberer CP, Wodnar-Filipowicz A: Human acute myeloid leukemia CD34 + CD38- stem cells are susceptible to allorecognition and lysis by single KIR-expressing natural killer cells. Haematologica 2009, 94:1590-1594.

30. Leiva M, Moretti S, Soilihi H, Pallavicini I, Peres L, Mercurio C, Dal Zuffo R, Minucci $S$, de Thé $H$ : Valproic acid induces differentiation and transient tumor regression, but spares leukemia-initiating activity in mouse models of APL. Leukemia 2012, 26:1630-1637.

31. Liu S, Klisovic RB, Vukosavljevic T, Yu J, Paschka P, Huynh L, Pang J, Neviani P, Liu Z, Blum W, Chan KK, Perrotti D, Marcucci G: Targeting AML1/ETO-histone deacetylase repressor complex: a novel mechanism for valproic acid-mediated gene expression and cellular differentiation in AML1/ETO-positive acute myeloid leukemia cells. J Pharmacol Exp Ther 2007, 321:953-960.

32. Lu X, Ohata K, Kondo Y, Espinoza JL, Qi Z, Nakao S: Hydroxyurea upregulates NKG2D ligand expression in myeloid leukemia cells synergistically with valproic acid and potentially enhances susceptibility of leukemic cells to natural killer cell-mediated cytolysis. Cancer Sci 2010, 101:609-615.

33. Patra SK, Deb M, Patra A: Molecular marks for epigenetic identification of developmental and cancer stem cells. Clin Epigenetics 2011, 2:27-53.

34. Poggi A, Catellani S, Garuti A, Pierri I, Gobbi M, Zocchi MR: Effective in vivo induction of NKG2D ligands in acute myeloid leukaemias by all-trans -retinoic acid or sodium valproate. Leukemia 2009, 23:641-648.

35. Skavland J, Jørgensen KM, Hadziavdic K, Hovland R, Jonassen I, Bruserud $\varnothing$ Gjertsen BT: Specific cellular signal-transduction responses to in vivo combination therapy with ATRA, valproic acid and theophylline in acute myeloid leukemia. Blood Cancer J 2011, 1:e4.

36. Smetana K, Zápotocký M: The effect of a histone deacetylase inhibitor - valproic acid - on nucleoli in human leukaemic myeloblasts. Folia Biol (Praha) 2010, 56:201-205.

37. Stapnes C, Ryningen A, Hatfield K, Øyan AM, Eide GE, Corbascio M, Kalland $\mathrm{KH}, \mathrm{Gjertsen} B \mathrm{~T}$, Bruserud $\varnothing$ : Functional characteristics and gene expression profiles of primary acute myeloid leukaemia cells identify patient subgroups that differ in susceptibility to histone deacetylase inhibitors. Int J Oncol 2007, 31:1529-1538.

38. St-Germain JR, Chen J, Li Q: Involvement of PML nuclear bodies in CBP degradation through the ubiquitin-proteasome pathway. Epigenetics 2008, 3:342-349.

39. Kuendgen A, Knipp S, Fox F, Strupp C, Hildebrandt B, Steidl C, Germing U, Haas R, Gattermann N: Results of a phase 2 study of valproic acid alone or in combination with all-trans retinoic acid in 75 patients with myelodysplastic syndrome and relapsed or refractory acute myeloid leukemia. Ann Hematol 2005, 84(Suppl 1):61-66.

40. Kuendgen A, Schmid M, Schlenk R, Knipp S, Hildebrandt B, Steidl C, Germing U, Haas R, Dohner H, Gattermann N: The histone deacetylase (HDAC) inhibitor valproic acid as monotherapy or in combination with all-trans retinoic acid in patients with acute myeloid leukemia. Cancer 2006, 106:112-119.
41. Breitman TR, Collins SJ, Keene BR: Terminal differentiation of human promyelocytic leukemic cells in primary culture in response to retinoic acid. Blood 1981, 57:1000-1004

42. Wang ZY, Chen Z: Acute promyelocytic leukemia: from highly fatal to highly curable. Blood 2008, 111:2505-2515.

43. Park JH, Tallman MS: Treatment of acute promyelocytic leukemia without cytotoxic chemotherapy. Oncology 2011, 25:733-741.

44. Mrózek K, Bloomfield CD: Clinical significance of the most common chromosome translocations in adult acute myeloid leukemia. J Natl Cancer Inst Monogr 2008, 39:52-57.

45. Ohnishi K: PML-RARalpha inhibitors (ATRA, tamibaroten, arsenic troxide) for acute promyelocytic leukemia. Int J Clin Oncol 2007, 12:313-317.

46. Trus MR, Yang L, Suarez Saiz F, Bordeleau L, Jurisica I, Minden MD: The histone deacetylase inhibitor valproic acid alters sensitivity towards all trans retinoic acid in acute myeloblastic leukemia cells. Leukemia 2005, 19:1161-1168.

47. Bellos F, Mahlknecht U: Valproic acid and all-trans retinoic acid: meta-analysis of a palliative treatment regimen in AML and MDS patients. Onkologie 2008, 31:629-633.

48. Bug G, Ritter M, Wassmann B, Schoch C, Heinzel T, Schwarz K, Romanski A, Kramer OH, Kampfmann M, Hoelzer D, Neubauer A, Ruthardt M, Ottmann OG: Clinical trial of valproic acid and all-trans retinoic acid in patients with poor-risk acute myeloid leukemia. Cancer 2005, 104:2717-2725.

49. Pilatrino C, Cilloni D, Messa E, Morotti A, Giugliano E, Pautasso M, Familiari U, Cappia S, Pelicci PG, Lo Coco F, Saglio G, Guerrasio A: Increase in platelet count in older, poor-risk patients with acute myeloid leukemia or myelodysplastic syndrome treated with valproic acid and all-trans retinoic acid. Cancer 2005, 104:101-109.

50. Raffoux E, Chaibi P, Dombret H, Degos L: Valproic acid and all-trans retinoic acid for the treatment of elderly patients with acute myeloid leukemia. Haematologica 2005, 90:986-988.

51. Ryningen A, Stapnes C, Lassalle P, Corbascio M, Gjertsen BT, Bruserud O: A subset of patients with high-risk acute myelogenous leukemia shows improved peripheral blood cell counts when treated with the combination of valproic acid, theophylline and all-trans retinoic acid. Leuk Res 2009, 33:779-787.

52. Cheson BD, Bennett JM, Kantarjian H, Pinto A, Schiffer CA, Nimer SD, Löwenberg B, Beran M, de Witte TM, Stone RM, Mittelman M, Sanz GF, Wijermans PW, Gore S, Greenberg PL, World Health Organization (WHO) international working group: Report of an international working group to standardize response criteria for myelodysplastic syndromes. Blood 2000, 96:3671-3674.

53. Cheson BD, Greenberg PL, Bennett JM, Lowenberg B, Wijermans PW, Nimer SD, Pinto A, Beran M, de Witte TM, Stone RM, Mittelman M, Sanz GF, Gore SD, Schiffer CA, Kantarjian H: Clinical application and proposal for modification of the International Working Group (IWG) response criteria in myelodysplasia. Blood 2006, 108:419-425.

54. Cheson BD, Bennett JM, Kopecky KJ, Büchner T, Willman CL, Estey EH, Schiffer CA, Doehner H, Tallman MS, Lister TA, Lo-Coco F, Willemze R, Biondi A, Hiddemann W, Larson RA, Löwenberg B, Sanz MA, Head DR, Ohno R, Bloomfield CD, International Working Group for Diagnosis, Standardization of Response Criteria, Treatment Outcomes, and Reporting Standards for Therapeutic Trials in Acute Myeloid Leukemia: Revised recommendations of the International Working Group for Diagnosis, Standardization of Response Criteria, Treatment Outcomes, and Reporting Standards for Therapeutic Trials in Acute Myeloid Leukemia. J Clin Oncol 2003, 21:4642-4649.

55. Fenaux P, Wang ZZ, Degos L: Treatment of acute promyelocytic leukemia by retinoids. Curr Top Microbiol Immunol 2007, 313:101-128.

56. Patatanian E, Thompson DF: Retinoic acid syndrome: a review. J Clin Pharm Ther 2008, 33:331-338.

57. Lübbert M, Suciu S, Baila L, Rüter BH, Platzbecker U, Giagounidis A, Selleslag D, Labar B, Germing U, Salih HR, Beeldens F, Muus P, Pflüger KH, Coens C, Hagemeijer A, Eckart Schaefer H, Ganser A, Aul C, de Witte T, Wijermans PW: Low-dose decitabine versus best supportive care in elderly patients with intermediate- or high-risk myelodysplastic syndrome (MDS) ineligible for intensive chemotherapy: final results of the randomized phase III study of the European Organisation for Research and Treatment of Cancer Leukemia Group and the German MDS Study Group. J Clin Oncol 2011, 29:1987-1996.

58. Cashen AF, Schiller GJ, O'Donnell MR, DiPersio JF: Multicenter, phase II study of decitabine for the first-line treatment of older patients with acute myeloid leukemia. J Clin Oncol 2010, 28:556-561.

59. Garcia-Manero G: Demethylating agents in myeloid malignancies. Curr Opin Oncol 2008, 20:705-710. 
60. Fenaux P, Mufti GJ, Hellstrom-Lindberg E, Santini V, Finelli C, Giagounidis A, Schoch R, Gattermann N, Sanz G, List A, Gore SD, Seymour JF, Bennett JM, Byrd J, Backstrom J, Zimmerman L, McKenzie D, Beach C, Silverman LR, International Vidaza High-Risk MDS Survival Study Group: Efficacy of azacitidine compared with that of conventional care regimens in the treatment of higher-risk myelodysplastic syndromes: a randomised open-label, phase III study. Lancet Oncol 2009, 10:223-232.

61. Fenaux P, Mufti GJ, Hellström-Lindberg E, Santini V, Gattermann N, Germing U, Sanz G, List AF, Gore S, Seymour JF, Dombret H, Backstrom J, Zimmerman L, McKenzie D, Beach CL, Silverman LR: Azacitidine prolongs overall survival compared with conventional care regimens in elderly patients with low bone marrow blast count acute myeloid leukemia. J Clin Oncol 2010, 28:562-569.

62. Lubbert M, Minden M: Decitabine in acute myeloid leukemia. Semin Hematol 2005, 42:S38-42.

63. Blum W, Klisovic RB, Hackanson B, Liu Z, Liu S, Devine H, Vukosavljevic T, Huynh L, Lozanski G, Kefauver C, Plass C, Devine SM, Heerema NA, Murgo A, Chan KK, Grever MR, Byrd JC, Marcucci G: Phase I study of decitabine alone or in combination with valproic acid in acute myeloid leukemia. J Clin Oncol 2007, 25:3884-3891.

64. Raffoux E, Cras A, Recher C, Boëlle PY, de Labarthe A, Turlure P, Marolleau JP, Reman O, Gardin C, Victor M, Maury S, Rousselot P, Malfuson JV, Maarek O, Daniel MT, Fenaux P, Degos L, Chomienne C, Chevret S, Dombret H: Phase 2 clinical trial of 5-azacitidine, valproic acid, and all-trans retinoic acid in patients with high-risk acute myeloid leukemia or myelodysplastic syndrome. Oncotarget 2010, 1:34-42.

65. Soriano AO, Yang H, Faderl S, Estrov Z, Giles F, Ravandi F, Cortes J, Wierda WG, Ouzounian S, Quezada A, Pierce S, Estey EH, Issa JP, Kantarjian HM, Garcia-Manero G: Safety and clinical activity of the combination of 5azacytidine, valproic acid, and all-trans retinoic acid in acute myeloid leukemia and myelodysplastic syndrome. Blood 2007, 110:2302-2308.

66. Garcia-Manero G, Kantarjian HM, Sanchez-Gonzalez B, Yang H, Rosner G, Verstovsek S, Rytting M, Wierda WG, Ravandi F, Koller C, Xiao L, Faderl S, Estrov Z, Cortes J, O'brien S, Estey E, Bueso-Ramos C, Fiorentino J, Jabbour E, Issa JP: Phase 1/2 study of the combination of 5-aza-2'-deoxycytidine with valproic acid in patients with leukemia. Blood 2006, 108:3271-3279.

67. Maslak P, Chanel S, Camacho LH, Soignet S, Pandolfi PP, Guernah I, Warrell R, Nimer S: Pilot study of combination transcriptional modulation therapy with sodium phenylbutyrate and 5-azacytidine in patients with acute myeloid leukemia or myelodysplastic syndrome. Leukemia 2006, 20:212-217.

68. Wagner JM, Hackanson B, Lübbert M, Jung M: Histone deacetylase (HDAC) inhibitors in recent clinical trials for cancer therapy. Clin Epigenetics 2010, 1:117-136.

69. Tambaro FP, Dell'aversana C, Carafa V, Nebbioso A, Radic B, Ferrara F, Altucci $\mathrm{L}$ : Histone deacetylase inhibitors: clinical implications for hematological malignancies. Clin Epigenetics 2010, 1:25-44.

70. Kadia TM, Yang H, Ferrajoli A, Maddipotti S, Schroeder C, Madden TL, Holleran $J$, Egorin MJ, Ravandi F, Thomas DA, Newsome W, Sanchez-Gonzalez B, Zwiebel JA, Espinoza-Delgado I, Kantarjian HM, Garcia-Manero G: A phase I study of vorinostat in combination with idarubicin in relapsed or refractory leukaemia. Br J Haematol 2010, 150:72-82.

71. Prebet $\mathrm{T}$, Vey $\mathrm{N}$ : Vorinostat in acute myeloid leukemia and myelodysplastic syndromes. Expert Opin Investig Drugs 2011, 20:287-295.

72. Schaefer EW, Loaiza-Bonilla A, Juckett M, DiPersio JF, Roy V, Slack J, Wu W, Laumann K, Espinoza-Delgado I, Gore SD, Mayo P2C Phase II Consortium: A phase 2 study of vorinostat in acute myeloid leukemia. Haematologica 2009, 94:1375-1382.

73. Walter RB, Medeiros BC, Powell BL, Schiffer CA, Appelbaum FR, Estey EH: Phase II trial of vorinostat and gemtuzumab ozogamicin as induction and post-remission therapy in older adults with previously untreated acute myeloid leukemia. Haematologica 2012, 97:739-742.

74. Garcia-Manero G, Yang H, Bueso-Ramos C, Ferrajoli A, Cortes J, Wierda WG, Faderl S, Koller C, Morris G, Rosner G, Loboda A, Fantin VR, Randolph SS, Hardwick JS, Reilly JF, Chen C, Ricker JL, Secrist JP, Richon VM, Frankel SR, Kantarjian HM: Phase 1 study of the histone deacetylase inhibitor vorinostat (suberoylanilide hydroxamic acid [SAHA]) in patients with advanced leukemias and myelodysplastic syndromes. Blood 2008, 111:1060-1066.

75. Berni Canani R, Di Costanzo M, Leone L: The epigenetic effects of butyrate: potential therapeutic implications for clinical practice. Clin Epigenetics 2012, 4:4.
76. Bruserud $\varnothing$, Stapnes $C$, Ersvaer E, Gjertsen BT, Ryningen A: Histone deacetylase inhibitors in cancer treatment: a review of the clinical toxicity and the modulation of gene expression in cancer cell. Curr Pharm Biotechnol 2007, 8:388-400.

77. Bruserud $\varnothing$, Stapnes C, Tronstad KJ, Ryningen A, Anensen N, Gjertsen BT: Protein lysine acetylation in normal and leukaemic haematopoiesis: HDACs as possible therapeutic targets in adult AML. Expert Opin Ther Targets 2006, 10:51-68.

78. Hubeek I, Kaspers G-J L, Ossenkoppele GJ, Peters GJ: Cytosine arabinoside: metabolism, mechanisms of resistance and clinical pharmacology. In Deoxynucleoside Analogs in Cancer Therapy. Edited by Peters GJ. Totowa, NJ: Humana Press; 2006:119-152 [Teicher BA (Series Editor): Cancer Drug Discovery and Development.].

79. Shipley JL, Butera JN: Acute myelogenous leukemia. Exp Hematol 2009, 37:649-658.

80. Bolwell BJ, Cassileth PA, Gale RP: Low dose cytosine arabinoside in myelodysplasia and acute myelogenous leukemia: a review. Leukemia 1987, 1:575-579.

81. Burnett AK, Hills RK, Hunter A, Milligan D, Kell J, Wheatley K, Yin J, McMullin MF, Cahalin P, Craig J, Bowen D, Russell N: The addition of arsenic trioxide to low-dose Ara-C in older patients with AML does not improve outcome. Leukemia 2011, 25:1122-1127.

82. Gu LF, Zhang WG, Wang FX, Cao XM, Chen YX, He AL, Liu J, Ma XR: Low dose of homoharringtonine and cytarabine combined with granulocyte colony-stimulating factor priming on the outcome of relapsed or refractory acute myeloid leukemia. J Cancer Res Clin Oncol 2011, 137:997-1003.

83. Roboz GJ, Ritchie EK, Curcio T, Provenzano J, Carlin R, Samuel M, Wittenberg B, Mazumdar M, Christos PJ, Mathew S, Allen-Bard S, Feldman EJ: Arsenic trioxide and low-dose cytarabine in older patients with untreated acute myeloid leukemia, excluding acute promyelocytic leukemia. Cancer 2008, 113:2504-2511.

84. Li JM, Shen Y, Wu DP, Liang H, Jin J, Chen FY, Song YP, Song EY, Qiu XF, Hou M, Qiu ZC, Shen ZX: Aclarubicin and low-dose Cytosine arabinoside in combination with granulocyte colony-stimulating factor in treating acute myeloid leukemia patients with relapsed or refractory disease and myelodysplastic syndrome: a multicenter study of 112 Chinese patients. Int J Hematol 2005, 82:48-54.

85. Fredly H, Ersvaer E, Stapnes C, Gjertsen BT, Bruserud O: The combination of conventional chemotherapy with new targeted therapy in hematologic malignancies: the safety and efficiency of low-dose cytarabine supports its combination with new therapeutic agents in early clinical trials. Curr Cancer Ther Rev 2009, 5:243-255.

86. Dingli D, Tefferi A: Hydroxyurea: The drug of choice for polycythemia vera and essential thrombocythemia. Curr Hematol Malig Rep 2006, 1:69-74.

87. Saban N, Bujak M: Hydroxyurea and hydroxamic acid derivatives as antitumor drugs. Cancer Chemother Pharmacol 2009, 64:213-221.

88. Latagliata R, Bongarzoni V, Carmosino I, Mengarelli A, Breccia M, Borza PA D'Andrea M, D'Elia GM, Mecarocci S, Morano SG, Petti MC, Mandelli F, Alimena G: Acute myelogenous leukemia in elderly patients not eligible for intensive chemotherapy: the dark side of the moon. Ann Oncol 2006, 17:281-285.

89. Burnett AK, Milligan D, Prentice AG, Goldstone AH, McMullin MF, Hills RK, Wheatley K: A comparison of low-dose cytarabine and hydroxyurea with or without all-trans retinoic acid for acute myeloid leukemia and high-risk myelodysplastic syndrome in patients not considered fit for intensive treatment. Cancer 2007, 109:1114-1124.

90. Petti MC, Tafuri A, Latagliata R, Aloe Spiriti MA, Montefusco E, Mancini M, Meloni G, Petrucci MT, Spadea A, Redi R, Alimena G, Mandelli F: High-dose hydroxyurea in the treatment of poor-risk myeloid leukemias. Ann Hematol 2003, 82:476-480.

91. Karran P: Thiopurines, DNA damage, DNA repair and therapy-related cancer. Br Med Bull 2006, 79-80:153-170.

92. Adam De Beaumais T, Jacqz-Aigrain E: Pharmacogenetic determinants of mercaptopurine disposition in children with acute lymphoblastic leukemia. Eur J Clin Pharmacol 2012, 68:1233-1242.

93. Mori M, Ohta M, Miyata A, Higashihara M, Oshimi K, Kimura H, Yagasaki F, Sunami K: Treatment of acute myeloid leukemia patients aged more than 75 years: results of the E-AML-01 trial of the Japanese Elderly Leukemia and Lymphoma Study Group (JELLSG). Leuk Lymphoma 2006, 47:2062-2069.

94. Miyawaki S, Sakamaki H, Ohtake S, Emi N, Yagasaki F, Mitani K, Matsuda S, Kishimoto Y, Miyazaki Y, Asou N, Matsushima T, Takahashi M, Ogawa Y, 
Honda S, Ohno R, Japan Adult Leukemia Study Group AML 97 Study: A randomized, postremission comparison of four courses of standard-dose consolidation therapy without maintenance therapy versus three courses of standard-dose consolidation with maintenance therapy in adults with acute myeloid leukemia: the Japan Adult Leukemia Study Group AML 97 Study. Cancer 2005, 104:2726-2734.

95. Fredly H, Ersvaer E, Kittang AO, Tsykunova G, Gjertsen BT, Bruserud O: The combination of valproic acid, all-trans retinoic acid and low-dose cytarabine as disease-stabilizing treatment in acute myeloid leukemia. Clin Epigenetics. in press.

96. Lane S, Gill D, McMillan NA, Saunders N, Murphy R, Spurr T, Keane C, Fan $H M$, Mollee P: Valproic acid combined with cytosine arabinoside in elderly patients with acute myeloid leukemia has in vitro but limited clinical activity. Leuk Lymphoma 2012, 53:1077-1083.

97. Bruserud O, Liseth K, Stamnesfet S, Cacic DL, Melve GK, Kristoffersen E, Hervig T, Reikvam H: Hyperleukocytosis and leukapheresis: a single centre experience with regard to apheresis technique and efficiency and a review of previous studies of leukapheresis in the treatment of acute myeloid leukemia. Transfus Med. in press.

98. Cai D, Wang Y, Ottmann OG, Barth PJ, Neubauer A, Burchert A: FLT3-ITD-, but not $B C R / A B L$-transformed cells require concurrent $A \mathrm{kt} / \mathrm{mTor}$ blockage to undergo apoptosis after histone deacetylase inhibitor treatment. Blood 2006, 107:2094-2097.

99. Candelaria M, Herrera A, Labardini J, González-Fierro A, Trejo-Becerril C, Taja-Chayeb L, Pérez-Cárdenas E, de la Cruz-Hernández E, Arias-Bofill D, Vidal S, Cervera E, Dueñas-Gonzalez A: Hydralazine and magnesium valproate as epigenetic treatment for myelodysplastic syndrome. Preliminary results of a phase-II trial. Ann Hematol 2011, 90:379-387.

100. Chen J, Wang G, Wang L, Kang J, Wang J: Curcumin p38-dependently enhances the anticancer activity of valproic acid in human leukemia cells. Eur J Pharm Sci 2010, 41:210-218.

101. Fabre C, Grosjean J, Tailler M, Boehrer S, Ades L, Perfettini JL, de Botton S, Fenaux $P$, Kroemer G: A novel effect of DNA methyltransferase and histone deacetylase inhibitors: NFkappaB inhibition in malignant myeloblasts. Cell Cycle 2008, 7:2139-2145.

102. Fuchs O, Provaznikova D, Marinov I, Kuzelova K, Spicka I: Antiproliferative and proapoptotic effects of proteasome inhibitors and their combination with histone deacetylase inhibitors on leukemia cells. Cardiovasc Hematol Disord Drug Targets 2009, 9:62-77.

103. McCormack E, Haaland I, Venås G, Forthun RB, Huseby S, Gausdal G, Knappskog S, Micklem DR, Lorens JB, Bruserud O, Gjertsen BT: Synergistic induction of p53 mediated apoptosis by valproic acid and nutlin-3 in acute myeloid leukemia. Leukemia 2012, 26:910-917.

104. Nie D, Huang K, Yin S, Li Y, Xie S, Ma L, Wang X, Wu Y, Xiao J: Synergistic/ additive interaction of valproic acid with bortezomib on proliferation and apoptosis of acute myeloid leukemia cells. Leuk Lymphoma 2012, 53:2487-2495.

105. Qi H, Ratnam M: Synergistic induction of folate receptor beta by all-trans retinoic acid and histone deacetylase inhibitors in acute myelogenous leukemia cells: mechanism and utility in enhancing selective growth inhibition by antifolates. Cancer Res 2006, 66:5875-5882.

106. Ryningen A, Reikvam H, Nepstad I, Paulsen Rye K, Bruserud $\varnothing$ : Inhibition of Mammalian target of rapamycin in human acute myeloid leukemia cells has diverse effects that depend on the environmental in vitro stress. Bone Marrow Res 2012, 2012:329061.

107. Wang AH, Wei L, Chen L, Zhao SQ, Wu WL, Shen ZX, Li JM: Synergistic effect of bortezomib and valproic acid treatment on the proliferation and apoptosis of acute myeloid leukemia and myelodysplastic syndrome cells. Ann Hematol 2011, 90:917-931.

108. Yu W, Wang J, Jin J, Qian W, Qian J, Cheng Y, Wang L: Heat shock protein 90 inhibition results in altered downstream signaling of mutant KIT and exerts synergistic effects on Kasumi- 1 cells when combining with histone deacetylase inhibitor. Leuk Res 2011, 35:1212-1218.

109. ten Cate B, Bremer E, de Bruyn M, Bijma T, Samplonius D, Schwemmlein M, Huls G, Fey G, Helfrich W: A novel AML-selective TRAIL fusion protein that is superior to Gemtuzumab Ozogamicin in terms of in vitro selectivity, activity and stability. Leukemia 2009, 23:1389-1397.

110. Ritchie EK, Roboz GJ: Levels of care: defining best supportive care in elderly patients with acute myeloid leukemia. Curr Hematol Malig Rep 2010, 5:95-100.

111. Menzin J, Lang K, Earle CC, Kerney D, Mallick R: The outcomes and costs of acute myeloid leukemia among the elderly. Arch Intern Med 2002, 162:1597-1603.
112. Deschler B, de Witte T, Mertelsmann R, Lübbert M: Treatment decision-making for older patients with high-risk myelodysplastic syndrome or acute myeloid leukemia: problems and approaches. Haematologica 2006, 91:1513-1522.

113. Greiner J, Döhner H, Schmitt M: Cancer vaccines for patients with acute myeloid leukemia-definition of leukemia-associated antigens and current clinical protocols targeting these antigens. Haematologica 2006, 91:1653-1661.

114. Bruserud $\varnothing$, Ersvaer $E$, Olsnes A, Gjertsen BT: Anticancer immunotherapy in combination with proapoptotic therapy. Curr Cancer Drug Targets 2008, 8:666-675

115. Fredly H, Ersvær E, Gjertsen BT, Bruserud O: Immunogenic apoptosis in human acute myeloid leukemia (AML): primary human AML cells expose calreticulin and release heat shock protein (HSP) 70 and HSP90 during apoptosis. Oncol Rep 2011, 25:1549-1556.

116. Flandrin P, Guyotat D, Duval A, Cornillon J, Tavernier E, Nadal N, Campos L: Significance of heat-shock protein (HSP) 90 expression in acute myeloid leukemia cells. Cell Stress Chaperones 2008, 13:357-364.

117. Steiner K, Graf M, Hecht K, Reif S, Rossbacher L, Pfister K, Kolb HJ, Schmetzer HM, Multhoff G: High HSP70-membrane expression on leukemic cells from patients with acute myeloid leukemia is associated with a worse prognosis. Leukemia 2006, 20:2076-2079.

118. Thomas X, Campos L, Mounier C, Cornillon J, Flandrin P, Le QH, Piselli S, Guyotat $D$ : Expression of heat-shock proteins is associated with major adverse prognostic factors in acute myeloid leukemia. Leuk Res 2005, 29:1049-1058.

119. Yeh CH, Tseng R, Hannah A, Estrov Z, Estey E, Kantarjian H, Albitar M: Clinical correlation of circulating heat shock protein 70 in acute leukemia. Leuk Res 2010, 34:605-609.

120. Liseth K, Ersvaer E, Hervig T, Bruserud $\varnothing$ : Combination of intensive chemotherapy and anticancer vaccines in the treatment of human malignancies: the hematological experience. J Biomed Biotechnol 2010, 2010:692097.

121. Alibhai SM, Leach M, Gupta V, Tomlinson GA, Brandwein JM, Saiz FS, Minden MD: Quality of life beyond 6 months after diagnosis in older adults with acute myeloid leukemia. Crit Rev Oncol Hematol 2009, 69:168-174.

122. Redaelli A, Stephens JM, Brandt S, Botteman MF, Pashos CL: Short- and long-term effects of acute myeloid leukemia on patient health-related quality of life. Cancer Treat Rev 2004, 30:103-117.

123. Alibhai SM, Leach M, Kermalli H, Gupta V, Kowgier ME, Tomlinson GA Brandwein J, Buckstein R, Minden MD: The impact of acute myeloid leukemia and its treatment on quality of life and functional status in older adults. Crit Rev Oncol Hematol 2007, 64:19-30.

124. Sekeres MA, Stone RM, Zahrieh D, Neuberg D, Morrison V, De Angelo DJ, Galinsky I, Lee SJ: Decision-making and quality of life in older adults with acute myeloid leukemia or advanced myelodysplastic syndrome. Leukemia 2004, 18:809-816.

125. Wisløff F, Gulbrandsen N, Hjorth M, Lenhoff S, Fayers P: Quality of life may be affected more by disease parameters and response to therapy than by haemoglobin changes. Eur J Haematol 2005, 75:293-298.

126. Jones PA, Baylin SB: The epigenomics of cancer. Cell 2007, 128:683-692.

127. Melnick AM: Epigenetics in AML. Best Pract Res Clin Haematol 2010, 23:463-468.

128. Jain N, Rossi A, Garcia-Manero G: Epigenetic therapy of leukemia: An update. Int J Biochem Cell Biol 2009, 41:72-80.

129. Cameron EE, Bachman KE, Myöhänen S, Herman JG, Baylin SB: Synergy of demethylation and histone deacetylase inhibition in the re-expression of genes silenced in cancer. Nat Genet 1999, 21:103-107.

130. Fahrner JA, Eguchi S, Herman JG, Baylin SB: Dependence of histone modifications and gene expression on DNA hypermethylation in cancer. Cancer Res 2002, 62:7213-7218.

131. Bennemann K, Galm O, Wilop S, Schubert C, Brummendorf TH, Jost E: Epigenetic dysregulation of secreted frizzled-related proteins in myeloproliferative neoplasms complements the JAK2V617F-mutation. Clin Epigenetics 2012, 4:12.

132. Mascarenhas J, Roper N, Chaurasia P, Hoffman R: Epigenetic abnormalities in myeloproliferative neoplasms: a target for novel therapeutic strategies. Clin Epigenetics 2011, 2:197-212.

doi:10.1186/1868-7083-5-12

Cite this article as: Fredly et al:: Histone deacetylase inhibition in the treatment of acute myeloid leukemia: the effects of valproic acid on leukemic cells, and the clinical and experimental evidence for combining valproic acid with other antileukemic agents. Clinical Epigenetics 2013 5:12. 